\title{
Growth and productivity of New Zealand kauri (Agathis australis (D.Don) Lindl.) in planted forests
}

\author{
Gregory A Steward ${ }^{1 *}$, Mark O Kimberley ${ }^{1}$, Euan G Mason² and Heidi S Dungey
}

\begin{abstract}
Background: The establishment of even-aged planted stands of New Zealand kauri (Agathis australis (D.Don) Lindl.) for timber has been constrained by a lack of quantitative information on productivity and rotation length on which forest management and investment decisions could be made.

Methods: Stand-level models of height and basal area against time were developed (as well as a stand-volume function to calculate volume from height and basal area) based on planted stands that were up to 83-years old and represented planting sites both within and outside the current natural range of the species.

Results: Planted kauri was shown to be slow to establish with little height growth for the first five years after planting. Similar trends were observed for basal area and whole-tree volume development. A Schumacher equation with local slope parameter and asymptote bounded at $45 \mathrm{~m}$ gave the best fit for height, while a von Bertalanffy-Richards equation in difference form with local slope parameter gave the best fit for basal area. For plantations with an average site index (20.4), height was predicted to be $22.3 \mathrm{~m}$ in height at age 60, with a basal area of $78.1 \mathrm{~m}^{2} \mathrm{ha}^{-1}$. Whole-tree volume was predicted to be $702 \mathrm{~m}^{3} \mathrm{ha}^{-1}$. Predicted volume mean annual increment was $11.7 \mathrm{~m}^{3} \mathrm{ha}^{-1} \mathrm{yr}^{-1}$ for all stands at age 60. From age 20-60 years, stands with a higher site index had a volume mean annual increment of $18.6 \mathrm{~m}^{3} \mathrm{ha}^{-1} \mathrm{yr}^{-1}$. The best stand exceeded $20 \mathrm{~m}^{3} \mathrm{ha}^{-1} \mathrm{yr}^{-1}$.
\end{abstract}

Conclusions: This study indicates an opportunity to grow kauri in plantations on selected good-quality sites over rotations of $60-80$ years or less.

Keywords: Height; Basal area; Volume; Difference equation; Non-linear mixed model; Indigenous plantations; Agathis australis

\section{Background}

Kauri is endemic to New Zealand, where it is the only indigenous member of the family Araucariaceae. It has the most southerly distribution of any species in the genus Agathis and its natural range is currently confined to the warm temperate areas of the North Island (Figure 1). It is found from sea level to elevations of approximately $360 \mathrm{~m}$ (Cockayne 1928); although a few trees exist at $800 \mathrm{~m}$ on the Coromandel Peninsula (Colenso 1868; Cranwell and Moore 1936; Hutchins 1919). The heartwood of mature kauri has the reputation of being one of the finest softwoods in the world (Clifton 1990; Cheeseman 1914; Von Hochstetter 1867) due to natural qualities of decay resistance and dimensional stability, particularly

\footnotetext{
* Correspondence: greg.steward@scionresearch.com

${ }^{1}$ New Zealand Forest Research Institute Ltd. (Scion), Private Bag 3020,

Rotorua, New Zealand

Full list of author information is available at the end of the article
}

under moist conditions. Kauri timber made a substantial contribution to the economic development of New Zealand between 1830 and 1900 (Steward and Beveridge 2010; Roche 1990). Exploitation of New Zealand kauri (in the 19th century) left a mature resource estimated to be only 7,500 hectares (Halkett 1983), with second-growth stands arising since land clearing estimated to be 60,000 hectares (Lloyd 1978; Halkett 1983). These natural stands are predominantly in the conservation estate (Steward and Beveridge 2010) and unavailable for management or harvest. The New Zealand timber market has consequently been left with a continued interest in kauri timber, but largely without a supply.

Planting of kauri for timber has become increasingly popular, but has been constrained by a lack of quantitative information on growth and productivity (New Zealand Forest Research Institute 1997), and hence rotation 


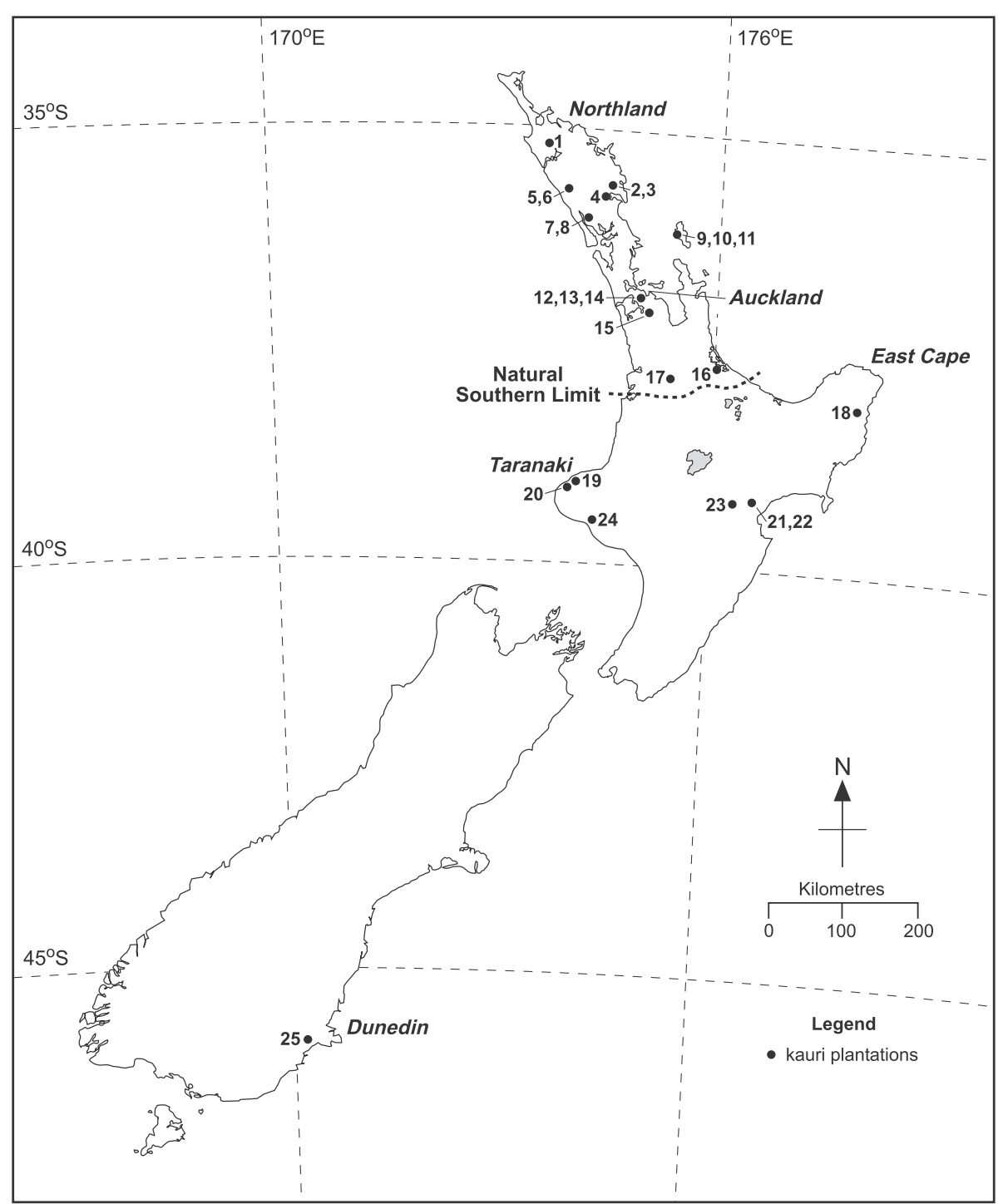

Figure 1 Location of the planted kauri stands from which the models of height, basal area and volume were developed. Eight of the stands were located south of the current natural limit of the species.

length and return on investment (Herbert et al. 1996; Steward 2011).

Early assumptions were that kauri would have to be grown to similar dimensions as trees in old-growth forest (Hutchins 1919), over rotations commonly assumed to be in the hundreds of years (Laing and Blackwell 1907). This followed the perceived need to replicate and recover large quantities of durable heartwood. As a consequence, only a small number of kauri forests were planted with any sense of replacing the original resource.

Initial estimates of productivity of kauri were based on data from natural stands (Lloyd 1978) and pole-kauri volume tables (Ellis 1979). The productivity by age in natural stands was assumed to be low (2.8-8.8 $\mathrm{m}^{3} \mathrm{ha}^{-1} \mathrm{yr}^{-1}$ ) (Halkett 1983) and directly applicable to planted stands. A comprehensive survey of the performance of a range of New Zealand indigenous species' identified kauri as one of the most commonly planted softwoods (Pardy et al. 1992). Annual growth of planted kauri averaged $0.7 \mathrm{~cm}$ in diameter and $0.36 \mathrm{~m}$ in height from a wide range of sites with different stocking rates and management history. These data were used to predict a mean annual height increment for planted kauri of $0.44 \mathrm{~m}$ at 20 years, reducing to $0.26 \mathrm{~m}$ at 80 years. This rate was among the highest for the indigenous conifers surveyed. Ecroyd et al. (1993) reported that in some kauri plantations average diameter growth exceeded $1.0 \mathrm{~cm} \mathrm{yr}^{-1}$ for periods of up to 40 years. Height increments of $1.0 \mathrm{~m} \mathrm{yr}^{-1}$ were recorded for individual trees. Productivity estimates were not developed from the data of either Pardy et al. (1992) or Ecroyd et al. (1982). 
Herbert et al. (1996) developed a preliminary stand productivity and economic model for planted kauri, based on two 60-year old stands growing outside the species current natural range in the Taranaki region (Figure 1). Models, based on the Chapman-Richards growth function (Richards 1959; Chapman 1961), of mean top height, basal area, and whole-stem volume were produced for stands at an average 1375 stems $\mathrm{ha}^{-1}$. Volume mean annual increment (MAI) was estimated to be $13.4 \mathrm{~m}^{3} \mathrm{ha}^{-1} \mathrm{yr}^{-1}$ at age 60 years, increasing to $13.8 \mathrm{~m}^{3} \mathrm{ha}^{-1} \mathrm{yr}^{-1}$ at age 80 years. Chikumbo and Steward (2007) developed a basal area model using data from thirteen planted stands. The dynamical modelling approach was based on a von Bertalanffy-Richards generalised growth function (Richards 1959; von Bertalanffy 1949) and led to the development of a state-space model that was asymptotically stable, and was valid for stand density within the range of 300-1,400 stems $\mathrm{ha}^{-1}$. Predicted basal-area values were similar to those of Herbert et al. (1996) until age 60. These earlier models were based on a limited number of planted stands and were not tested against other kauri plantings. They were therefore not necessarily reflective of the overall performance of the species and could not be considered suitable for general use across New Zealand. More robust models were expected to provide the basis for further model development and validation as more data became available.

The objectives of this study were to:

- compile the largest available data set of growth yet developed for New Zealand kauri in planted stands,

- determine the productivity of kauri grown in plantations across a range of sites and conditions,

- determine whether improved growth rates would result in shorter rotation lengths for commercial harvest.

Hypotheses were tested by developing and validating robust stand-level models for height, basal area and standing whole-tree volume. These models will facilitate early predictions from which investment and management decisions can be made for kauri forestry in New Zealand in the future.

\section{Methods}

This study concentrated on the development of planted kauri at the stand level, therefore the variables of height, basal area and volume were emphasised. The number of stands available, the variability in stand density, and periodicity of measurement did not allow for the development of models of diameter at breast height (DBH), mortality, or a thinning function. However, mortality and the relationship between stand density (stems $\mathrm{ha}^{-1}$ ) and mean diameter were characterised.

\section{Study sites}

Twenty-five planted stands with varying histories of measurement were used in this study. Twenty-four of the stands were located in the North Island of New Zealand. Eight stands were planted south of the current natural southern limit described for kauri (Sando 1936; Von Hochstetter 1867) (Figure 1). Only one stand (Stand 25) was located in the South Island (latitude $45.83{ }^{\circ} \mathrm{S}$ ), some 1200 kilometres south of the most northerly stand. Stands ranged from 4-71 years at the first assessment, and from 12-83 years at the last assessment. Ten stands were in the 50-59 year age class and were established during a major plantation programme by the New Zealand Forest Service in the 1950s. Individual stands in this study have been observed by different groups for periods of 2-50 years. Initial stand density (at planting) ranged from 320-2,240 stems $\mathrm{ha}^{-1}$ (mean 1,096 stems ha ${ }^{-1}$ ) (Table 1). Site elevation averaged $117 \mathrm{~m}$ above sea level, but was as high as $440 \mathrm{~m}$, and as low as $20 \mathrm{~m}$ for five stands. Stands planted outside the species' natural range tended to be planted on hill country at higher than average elevation (mean $217 \mathrm{~m}$ ). Annual rainfall averaged $1,495 \mathrm{~mm}$. Highest rainfall occurred at the site with the highest elevation. Average annual sunshine was 2,031 hours. The most southern stand recorded the lowest sunshine hours (1,631 hours), mean annual temperature $\left(10.5^{\circ} \mathrm{C}\right)$ and annual rainfall (770 $\mathrm{mm}$ ) (a full summary of individual stands is contained in Additional file 1). The majority of stands were established without a nurse crop as described by Bergin and Gea (2007), or over-storey species. Where a vegetative cover existed at establishment, the survival and growth of kauri was not expected to have been influenced.

\section{Data}

Data were obtained from permanent sample plots (PSP) (Ellis and Hayes 1991) established in the interior of the stands. In larger stands more than one PSP was established. Small stands typically had adjoining forest comprised of species of equal stature and similar growth rate to kauri, therefore all stems were used, including those that would otherwise be defined as edge-trees (Cancino 2005). In 1986, Pardy et al. (1992) established growth plots to obtain data on the height and diameter growth of planted kauri. During the 1986 assessments, all measured trees were tagged. In later measurements, PSPs were overlaid to include previous growth plots. For each PSP, data were gathered on diameter of all stems at $1.4 \mathrm{~m}$ breast height; total tree height of selected stems; planting pattern; current and initial stand density; current stand age; survival/mortality; site characteristics (elevation, annual sunshine hours, rainfall and daily mean temperature). Not all kauri were measured for height, so unmeasured heights were estimated by fitting non-linear regression curves to the height and diameter data for each stand, at each measurement 
Table 1 Initial stand density and site characteristics of all planted kauri stands

\begin{tabular}{lllllll}
\hline & Initial stand density $\left(\mathbf{s t e m s}_{\mathbf{~ h a}}{ }^{\mathbf{1}}\right.$ ) & Elevation $(\mathbf{m})$ & Annual rainfall $(\mathbf{m m})$ & Annual sunshine hrs & Daily mean temp $\left({ }^{\circ} \mathbf{C}\right)$ & Latitude $\left({ }^{\circ} \mathbf{S}\right)$ \\
\hline Mean & 1096 & 117 & 1495 & 2031 & 14.0 & 37.44 \\
Min. & 320 & 20 & 770 & 1631 & 10.5 & 35.16 \\
Max. & 2240 & 440 & 2000 & 2260 & 15.7 & 45.83 \\
s.e. & 101.8 & 21.1 & 54.6 & 23.2 & 0.2 & - \\
s.d. & 566.8 & 117.4 & 304.1 & 129.1 & 1.2 & - \\
\hline
\end{tabular}

Climate data was obtained from New Zealand Meteorological Service (1983), elevation and latitude were derived from Department of Survey and Land Information (1989).

period. Predicted heights were calculated for each stand at each measurement period and estimated heights were entered onto the database.

\section{Analysis}

To compare performance between stands, all measurements were converted to a per hectare basis. Mean top height (MTH), mean top diameter, quadratic diameter, basal area per hectare, volume per hectare and survival/mortality were calculated. The average height and diameter of the 100 largest-diameter stems per hectare were used to calculate mean top height and mean top diameter. Average tree diameter was defined as quadratic mean diameter. Basal area was defined as the calculated sum per hectare of cross-sectional stem area at breast height (1.4 $\mathrm{m}$ above ground). Total standing volume/ha was calculated as the sum of individual tree volumes predicted by the pole-kauri volume table (Equation 1) (Ellis 1979).

$$
V=2.071 \ln (D)+0.839 \ln (H)-3.139
$$

where $V=$ total stem volume $\mathrm{m} 3 ; D=$ diameter at breast height $(\mathrm{cm}) ; H=$ total tree height $(\mathrm{m})$

For kauri in planted stands site index ${ }^{\mathrm{a}}$ was defined as mean top height at age 50, and was calculated from the height model.

\section{Modelling}

Three commonly used forms of sigmoidal growth function were tested for modelling height and basal area as a function of age $(T)$. These were the von Bertalanffy-Richards (Pienaar and Turnbull 1973; Richards 1959; von Bertalanffy 1949), the Schumacher (Schumacher 1939) and the Weibull (Weibull 1939; Yang et al. 1978) models (Table 2). Various forms of each model were tested along with several different methods of estimating their parameters. When used for height modelling, all models had an intercept of $0.5 \mathrm{~m}$ on the assumption that seedlings were this height when planted. For basal area, the same model forms were tested except that an intercept of zero was used although it is accepted that basal area does not exist until a height of $1.4 \mathrm{~m}$ is achieved. All models incorporated three parameters that are referred to as the asymptote $(a)$, slope $(b)$ and shape $(c)$ parameters.

For the von Bertalanffy-Richards model, two general methods of fitting the different forms of each model were tested. Firstly, the SAS Version 9.1 NLMIXED procedure was used (Littell et al. 1996). In this approach, one of the parameters was specified as a local parameter which varies with each site. This parameter was assumed to be randomly distributed from a normal distribution. Various forms in which either the slope or asymptote were assumed local were tested, along with more complex versions in which both slope and asymptote varied as functions of a local parameter. When using NLMIXED, the dependent variable was height (or basal area), and the independent variable was age. Secondly, the difference form of each equation was created and fitted using the SAS NLIN procedure. Two forms of difference equation in which the slope or the asymptote parameter was eliminated were tested. In this method of fitting the model, the function was fitted using adjacent pairs of measurements. The mean number of measurement intervals was 3.3 (range 1-10). The dependent variable was the second measurement (of height or basal area) and the independent variable was the first measurement of each pair. The model forms tested for the Schumacher model were similar to those tested for the von Bertalanffy-Richards model. Early attempts at fitting the Schumacher model for height produced extreme estimates for the asymptote (a parameter) (e.g. $>150 \mathrm{~m}$ ). The known maximum height recorded for kauri is $60 \mathrm{~m}$ (Ecroyd 1982). In planted stands, a maximum mean top height of $29 \mathrm{~m}$ was recorded. Therefore a height of $45.0 \mathrm{~m}$ was considered an acceptable compromise between the extreme maximum and the measured heights found in comparatively young

Table 2 Three sigmoidal growth functions (in yield form) from which mean top height and basal area models were developed

\begin{tabular}{ll}
\hline Equation & \\
\hline von Bertalanffy-Richards & $y=a\left(1-e^{-b T}\right)^{c}$ \\
Schumacher & $y=a e^{\left(-b T^{c}\right)}$ \\
Weibull & $y=a\left(1-e^{-b T^{c}}\right)$ \\
\hline
\end{tabular}


planted stands. For the Weibull models, only the simple yield and the nonlinear mixed models (NLMIXED) with local slope parameter were tested. Early analysis showed that this sigmoidal model was inferior to either the von Bertalanffy-Richards or Schumacher models and produced predictions that did not reflect the data.

Final fitted models were selected that had the smallest root mean square error (RMSE) and least biased residuals (Additional file 2). Predicted MTH, basal area or volume were calculated for each stand at each measurement period and subtracted from the actual measured value. The residuals were plotted by predicted values and interval length. The normality of residual distributions was a third criterion for model selection.

Two stand-level volume functions were fitted to the per hectare estimates of volume. Predicted basal area (G) and mean top height values for each site index were used in conjunction with the stand-level volume functions to provide predicted volumes. The volume function of Beekhuis (1966) was tested but tended to over-predict volume from age 30 . The generalised volume function $\left(V=b \times G^{a} \times M T H^{c}\right)$ gave the best fit to the data.

To validate the models for planted kauri, the one-at-atime cross-validation method was used. Cross-validation is a method for testing models where datasets are too small to divide into training and test sets, and can be used for estimating prediction error (Efron and Tibshirani 1993). The models were re-fitted to the data, leaving out one stand at a time. New parameter estimates were acquired and the models were refitted and root mean square error (RMSE) and bias were calculated.

The relationship between stand density and diameter for kauri (self-thinning function) (Reineke 1933; Yoda et al. 1963), was determined by establishing temporary plots in forests where kauri was the dominant species (numerically and/or basal area) and full site occupancy was assumed. Stem counts (stand density) for all species and their diameters were obtained. Additional data were obtained from Ahmed and Ogden (1987) from a study of 25 kauri forests throughout the species natural range. The quadratic mean diameter and stem density were calculated for each site and the data were graphed on logarithmic scales and a regression equation fitted.

Mortality for all stands was assessed at each measurement. It was calculated as percentage loss and percentage loss per year $\left(\% \mathrm{yr}^{-1}\right)$. Mortality was calculated for three periods (1) planting to the first assessment, (2) first to last assessment, and (3) over the entire rotation.

\section{Results}

The per-hectare summary data consisted of 121 plot measurements from 31 permanent sample plots within 25 planted kauri stands in New Zealand. At their last assessment, stands averaged 50.5 years of age and were at a stand density of 791.7 stems ha ${ }^{-1}$ (Table 3). Mean diameter for all stands was $31.1 \mathrm{~cm}$ and mean top height was $19.2 \mathrm{~m}$. Basal area averaged $59.8 \mathrm{~m}^{2} \mathrm{ha}^{-1}$. Whole-tree volume averaged $538.9 \mathrm{~m}^{3} \mathrm{ha}^{-1}$ (a summary of all sites can be found in Additional file 3).

\section{Height}

Height increment averaged $0.42 \mathrm{~m} \mathrm{yr}^{-1}$ over all sites (Figure 2). Younger stands (12-49 years) averaged $0.5 \mathrm{~m} \mathrm{yr}^{-1}$ for height increment, with those $>50$ years averaging $0.36 \mathrm{~m} \mathrm{yr}^{-1}$. By age 70 years, height increment was consistently less than $0.3 \mathrm{~m} \mathrm{yr}^{-1}$. Mean annual height increment was similar in stands that were within and outside the species' natural range ( $p$-value 0.875$)$. Height growth was not affected by stand density ( $p$-value 0.872 ). Height growth (mean top height) was strongly correlated to age for all planted stands $(r=0.938, p<0.001)$. Mean annual height increment was negatively correlated with stand age $(r=-0.824, p<0.001)$.

Site Index (at age 50 years) was calculated for all planted kauri stands. Maximum site index was $28.4 \mathrm{~m}$, while the lowest was $15.8 \mathrm{~m}$, and mean Site Index was $20.4 \mathrm{~m}$. Site index values were compared (Pearson correlation) with site parameters. Kauri height growth as expressed by Site Index was not influenced by the site parameters of elevation ( $r=-0.073, p$-value 0.727$)$, annual rainfall $(\mathrm{r}=-0.054, p$-value 0.797$)$, annual sunshine hours $(\mathrm{r}=0.052, p$-value 0.807$)$, daily mean temperature $(\mathrm{r}=-0.045, p$-value 0.830$)$ and latitude $(\mathrm{r}=0.146, p$-value $0.486)$. Site index was negatively correlated with age $(\mathrm{r}=-0.642, p$-value 0.000$)$, younger stands $<20$ years-old tending to have a higher site index predicted than older stands.

Schumacher models with a local slope $(b)$ parameter performed best for modelling height growth of kauri. The Schumacher anamorphic model in difference form with the $a$ (asymptote) parameter bounded gave the best fit using the following form (Equation 2),

$$
M T H=0.5+a \times \exp \left(\left((T / 50)^{c}\right) \times \ln ((S I-0.5) / a)\right)
$$

where $\mathrm{MTH}=$ mean top height; $\mathrm{T}=$ age; $0.5=$ starting height of seedlings; $a$ =bounded asymptote parameter estimate; $c=$ shape parameter estimate; SI $=$ Site Index (mean top height at age 50).

The residuals of observed-predicted height (Figure 3) were plotted by age and by interval length and showed little bias (mean $0.09 \mathrm{~m}$ ) and RMSE (1.301). Growth trajectories for MTH were plotted and showed little variation despite stands ranging in age from 12-83 years and from 320-2,000 stems ha ${ }^{-1}$ (Figure 4). Growth in early years after planting was slow until age 10 when height MAI was under $0.3 \mathrm{~m}$ yr. Until age 40, height MAI increased to over $0.4 \mathrm{~m} \mathrm{yr}^{-1}$, and then declined. For better performing 
Table 3 Mean performance of kauri in planted stands at their last assessment

\begin{tabular}{|c|c|c|c|c|c|c|c|}
\hline & Age (years) & $\begin{array}{l}\text { Stand density } \\
\left(\text { stems } \mathrm{ha}^{-1}\right)\end{array}$ & $\begin{array}{l}\text { Quadratic mean } \\
\text { DBH }(\mathrm{cm})\end{array}$ & $\begin{array}{l}\text { Mean top } \\
\text { DBH }(\mathrm{cm})\end{array}$ & $\begin{array}{l}\text { Mean top } \\
\text { height }(\mathrm{m})\end{array}$ & $\begin{array}{l}\text { Basal area } \\
\left(\mathrm{m}^{2} \mathrm{ha}^{-1}\right)\end{array}$ & $\begin{array}{l}\text { Volume } \\
\left(\mathrm{m}^{3} \mathrm{ha}^{-1}\right)\end{array}$ \\
\hline Mean & 50.5 & 791.7 & 31.1 & 38.4 & 19.2 & 59.8 & 538.9 \\
\hline Min. & 12 & 218 & 8.0 & 13.0 & 6.0 & 3.0 & 9.0 \\
\hline Max. & 83 & 1845 & 52.0 & 62.0 & 29.0 & 106.0 & 1184.0 \\
\hline s.d. & 21.3 & 402.0 & 11.2 & 12.6 & 5.9 & 31.1 & 322.6 \\
\hline s.e. & 3.8 & 72.2 & 2.0 & 2.3 & 1.1 & 5.6 & 57.9 \\
\hline
\end{tabular}

stands, height MAI was as high as $0.52 \mathrm{~m} \mathrm{yr}^{-1}$ until age 20 , and above $0.40 \mathrm{~m} \mathrm{yr}^{-1}$ until age 60 , before declining. Parameter estimates (and their standard errors) for the anamorphic Schumacher MTH model $\left(R^{2}=0.96\right)$ for planted kauri stands were $a=44.5$ (bounded) and $c=-0.7903$ (s.e. 0.025). Sigmoidal curves produced from this model reflected the actual data.

\section{Basal area}

Basal area mean annual increment (MAI) development was slow in the 10-15 years after planting at 0.26 $0.48 \mathrm{~m}^{2} \mathrm{ha}^{-1} \mathrm{yr}^{-1}$ (Figure 5). By age 60, basal area was $78.1 \mathrm{~m}^{2} \mathrm{ha}^{-1}$, and did not approach its maximum until age 70 years in best performing planted stands.

Equations described in Table 2 were used to model basal area growth using a starting value of 0 . Equations with a local slope parameter performed best. The polymorphic von Bertalanffy-Richards equation in difference form with local slope parameter had the lowest bias (0.44) and RMSE (7.58) (Figure 6) and was chosen as the best fit (Equation 3, Figure 7). The form of this model for projecting a measurement of basal area $\mathrm{G} 1$ at age T1 forward to age $\mathrm{T}$ is:

$$
G=a \times\left(1-\left(1-\left(\left(G_{i} / a\right)^{1 / c}\right)^{T / T_{i}}\right)\right)^{c}
$$

where $\mathrm{G}=$ predicted basal area; $\mathrm{G}_{i}=$ basal area at initial measurement; $\mathrm{T}=$ age of prediction; $\mathrm{T}_{i}=$ age of initial

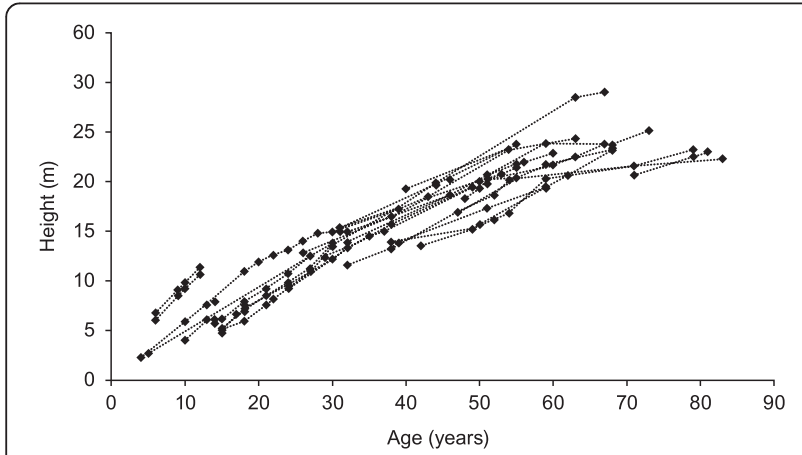

Figure 2 Development of height $(\mathrm{m})$ of kauri in 25 planted stands from age 4-83 years. Data points for individual stands are connected. measurement; $a=$ asymptote parameter estimate; $c=$ shape parameter estimate. Parameter estimates (and their standard errors) for the polymorphic von Bertalanffy-Richards basal area model $\left(R^{2}=0.95\right)$ for planted kauri stands were a 101.4 (s.e. 6.7) and $c 5.697$ (s.e. 0.642).

\section{Volume}

Whole-tree volume averaged $596.4 \mathrm{~m}^{3} \mathrm{ha}^{-1}$ for all planted kauri stands (Figure 8). The highest volume and volume MAI was in a 67-year old stand $\left(1,184 \mathrm{~m}^{3} \mathrm{ha}^{-1}\right.$, $\left.17.67 \mathrm{~m}^{3} \mathrm{ha}^{-1} \mathrm{yr}^{-1}\right)$. The lowest volume was in an 18year-old stand $\left(10.0 \mathrm{~m}^{3} \mathrm{ha}^{-1}, 0.55 \mathrm{~m}^{3} \mathrm{ha}^{-1} \mathrm{yr}^{-1}\right)$. Volume MAI averaged $10.3 \mathrm{~m}^{3} \mathrm{ha}^{-1} \mathrm{yr}^{-1}$ for all stands. Volume exceeded $800 \mathrm{~m}^{3} \mathrm{ha}^{-1}$ (MAI $12.9 \mathrm{~m}^{3} \mathrm{ha}^{-1} \mathrm{yr}^{-1}$ ) in stands that averaged 62 years and 1,169 stems ha ${ }^{-1}$. By age 30 years, kauri in planted stands had not exceeded $4.5 \mathrm{~m}^{3} \mathrm{ha}^{-1} \mathrm{yr}^{-1} \mathrm{MAI}$, and by age 50 years MAI averaged $7.3 \mathrm{~m}^{3} \mathrm{ha}^{-1} \mathrm{yr}^{-1}$.

Of the two volume models tested, the generalised volume function (Equation 4) gave the best fit to the data.

$$
V=b \times G^{a} \times P M H^{c}
$$

where $V=$ volume; $G=$ basal area; $M T H=$ mean top height; $a=$ asymptote parameter estimate; $b=$ slope parameter; $c=$ shape parameter estimate.

Parameter estimates (and their standard errors) for the volume model for planted kauri stands $\left(R^{2}=0.99\right)$ were

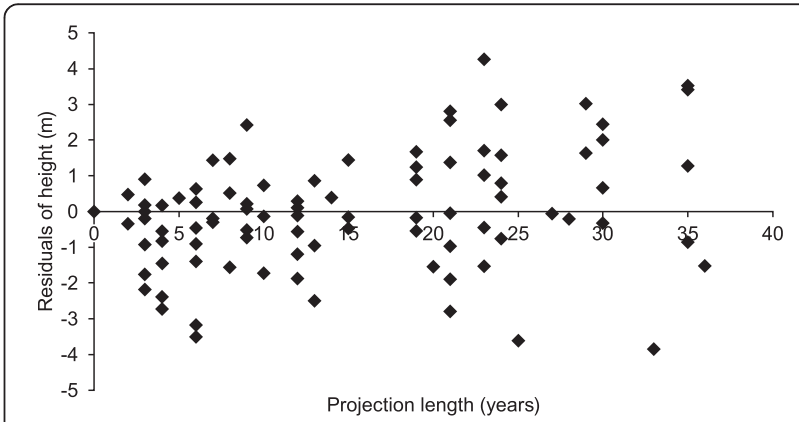

Figure 3 Residuals of mean top height plotted against projection length for kauri grown in planted stands (RMSE $=1.301$, mean $=0.09$ ). 


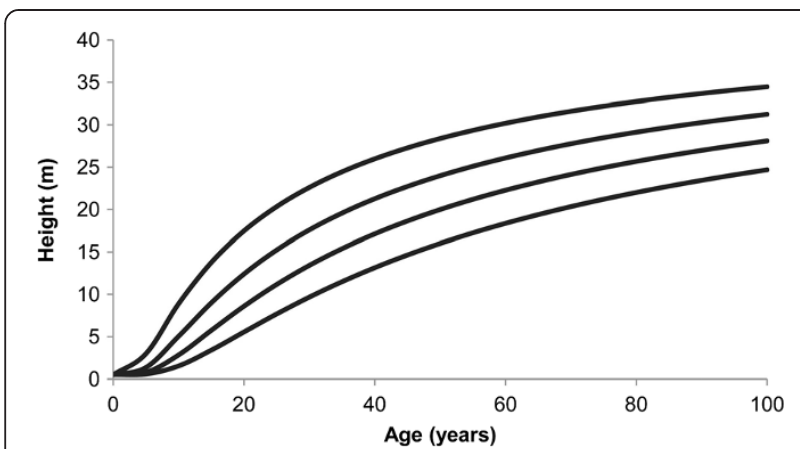

Figure 4 Anamorphic height/age curves for planted kauri. Height/age curves cover the range of site index values (at age 50 years) for planted kauri and are based on actual measurements to age 83 (Site indexes represented are 16, 20, 24 and 28).

$a 0.956$ (s.e. 0.089 ), $b 0.703$ (s.e. 0.03 ), and $c 0.883$ (s.e. $0.048)$.

A plot of residuals against actual volume showed little apparent bias (Figure 9). Volume was slow to develop with little volume in most stands before age 20 (Figure 10, Table 4). By age 60 years volume was estimated to be in excess of $700 \mathrm{~m}^{3} \mathrm{ha}^{-1}$ for mid-performing stands, with MAI at $11.7 \mathrm{~m}^{3} \mathrm{ha}^{-1} \mathrm{yr}^{-1}$. Current annual increment peaked at age 60 years at $18.0 \mathrm{~m}^{3} \mathrm{ha}^{-1} \mathrm{yr}^{-1}$. All stands showed good agreement between the volumes predicted by the volume model and the actual data points at each measurement.

\section{Model validation}

For both MTH and basal area cross validation resulted in an increased RMSE (Table 5), but bias was either similar or marginally smaller. The results indicate a good fit for models to predict height growth and productivity for stands planted on a wide range of sites throughout New Zealand.

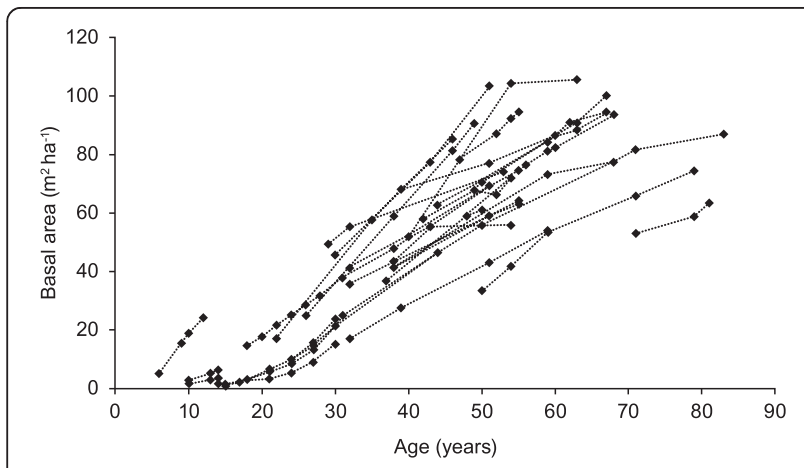

Figure 5 Development of basal area $\left(\mathrm{m}^{2} \mathrm{ha}^{-1}\right)$ of kauri in 25 planted stands from age 4-83 years. Data points for individual stands are connected.

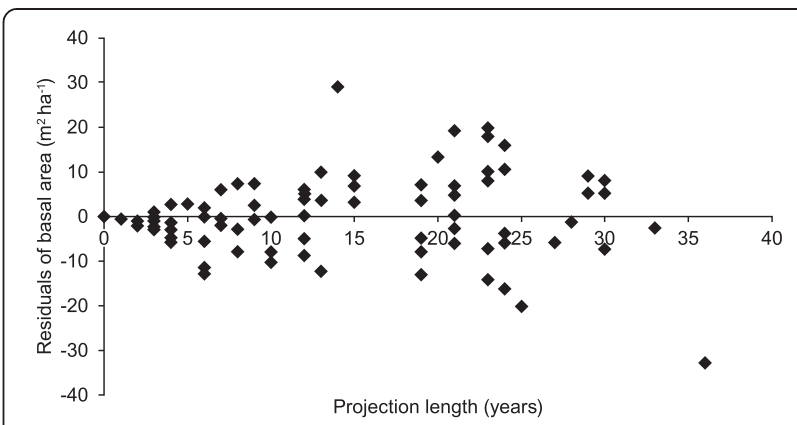

Figure 6 Residuals of basal area plotted against projection length for all planted kauri (RMSE $=7.58$, mean $=0.44$ ).

\section{Self-thinning}

Kauri averaged $91.5 \%$ (range $55.1-100 \%$ ) of the species count and $96.7 \%$ of the basal area $\left(\mathrm{m}^{2} \mathrm{ha}^{-1}\right.$ ) (range $74.4-$ $100 \%)$ in the stands used to determine self-thinning. In stands where kauri averaged only $56.1 \%$ of the species count, the other species tended to be numerous in number but small in diameter, consequently the kauri basal area component was still very high (average 86\%). Quadratic diameter of kauri was strongly correlated $\left(R^{2}=0.89\right)$ with current stand density (SD) (Figure 11) and the following self-thinning function was used to describe the relationship (Equation 5)

$$
\text { Quadratic mean diameter }=660.69 \times S D^{-0.456}
$$

\section{Mortality}

Mortality from planting across all stands was 22.1\% (range 1.8-52.5\%) (Figure 12). Initial stand density affected mortality. Stands with lower initial stand density $(<999$ stems $\mathrm{ha}^{-1}$ ) averaged $19.3 \%$ mortality while stands $>1000$ stems $\mathrm{ha}^{-1}$ averaged $24.7 \%$ mortality, and stands $>1500$ stems ha ${ }^{-1}$ averaged $27.8 \%$ mortality. The highest rate of

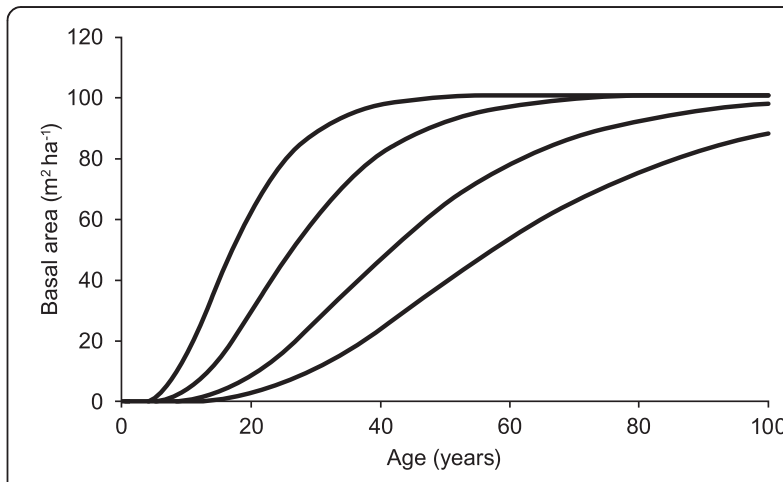

Figure 7 Polymorphic basal area curves for planted kauri covering the range of basal areas predicted in all planted kauri stands (curves are for site indexes 39, 65, 92 and $100 \mathrm{~m}^{2} \mathrm{ha}^{-1}$ at age 50 years). 


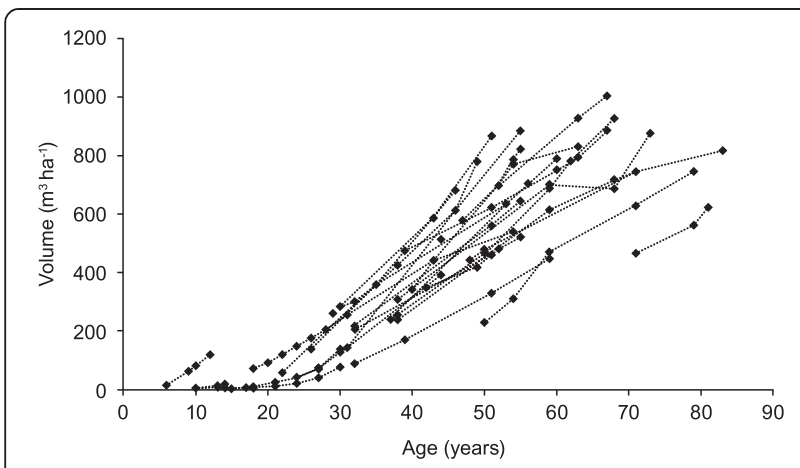

Figure 8 Development of volume $\left(\mathrm{m}^{3} \mathrm{ha}^{-1}\right)$ of kauri in 25 planted stands from age 4-83 years. Data points for individual stands are connected. mortality for all stands occurred in the years prior to the first assessment and averaged $0.64 \% \mathrm{yr}^{-1}$ (range 0.0-3.9). High early mortality was caused by drought, and was $3.9 \%$ $\mathrm{yr}^{-1}$ from planting to the first assessment in one stand. Over the entire rotation (planting to the last assessment) mortality in all stands averaged $0.56 \% \mathrm{yr}^{-1}$ (range 0.0-3.9). When drought-affected stands were removed, mortality was $0.4 \% \mathrm{yr}^{-1}$. During the period of observation for all stands (first to last assessment) mortality averaged $0.3 \% \mathrm{yr}^{-1}$ (range 0.0-2.6), and reduced further when drought-affected sites were excluded.

\section{Discussion and conclusions}

The height model produced in the current study was compared with the model for mean top height produced by Herbert et al. (1996). The height model of Herbert et al. based on two planted stands and measurements to age 60 years fitted the current model reasonably well, even when extrapolated to age 100 years (Figure 13). The slight difference in shape may be explained by the current model being based on the Schumacher growth function with data from 25 stands, while the Herbert et al. model was based on the von Bertalanffy-Richards growth function using data from only two highly stocked stands.

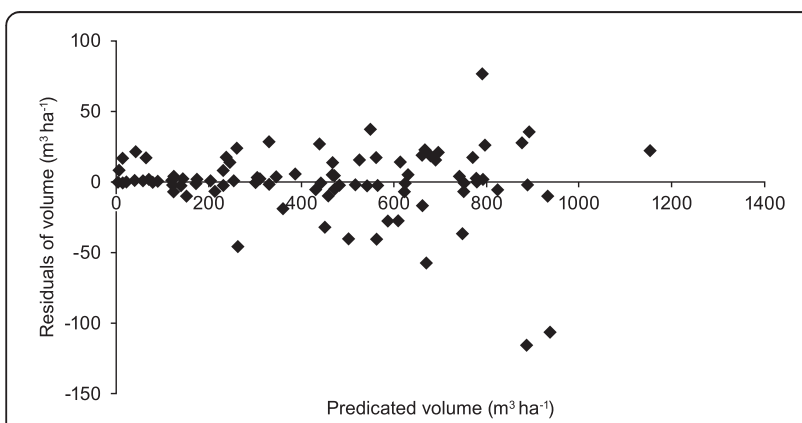

Figure 9 Residuals of volume plotted against predicted volume $($ RMSE $=14.91$, Mean $=0.91)$.

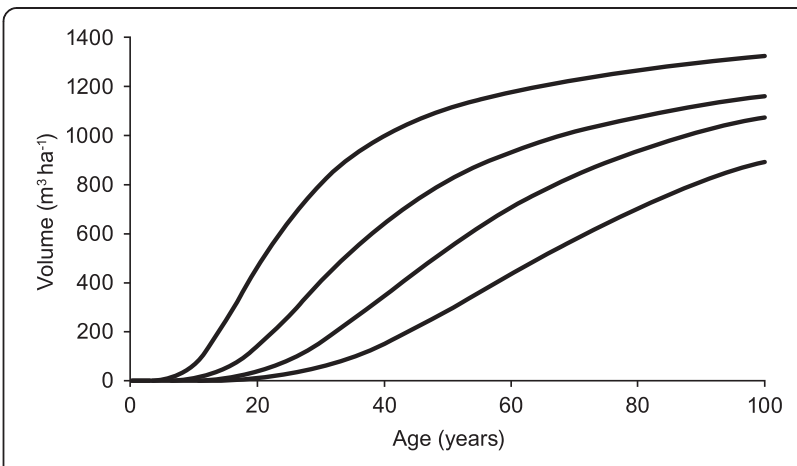

Figure 10 Volume/age curves for kauri from measurements of 25 planted stands $(\mathrm{RMSE}=14.91$, bias $=0.91$ ). Volume curves were developed from the height and basal area curves shown in Figures 4 and 7 , respectively).

The basal area model from the current study was compared with the two earlier basal area models of Herbert et al. (1996) and Chikumbo and Steward (2007). In each study the basal area models were based on the von Bertalanffy-Richards growth function. In the current study and that of Chikumbo and Steward (2007), the growth function of von Bertalanffy-Richards was in difference form. Until around age 40 years, all models were in general agreement (Figure 14). The predictions of Herbert et al. (1996) from age 20 years to 60 years were almost linear and had an assumption that diameter MAI was unlikely to fall below $2.0 \mathrm{~mm} \mathrm{yr}^{-1}$. This assumption was not supported by subsequent measurements of the same stands prior to thinning operations in 2002 and 2004 when diameter MAI had almost stopped (G. Steward pers. obs.). Diameter current annual increment (CAI) had reduced to $0.10-0.26 \mathrm{~cm} \mathrm{yr}^{-1}$, with stand density at both sites still in excess of 1,000 stems ha ${ }^{-1}$. From age 60 the extrapolated predictions of Herbert et al. (1996) were also not supported by either the current study or that of Chikumbo and Steward (2007). This suggests that, without thinning, the basal area predicted would not be achieved without intervention. Diameter increment two years after thinning of these stands had increased to $0.36 \mathrm{~cm} \mathrm{yr}^{-1}$. The basal area model of Chikumbo and Steward (2007) was in general agreement with the current model.

The volume model from the current study was compared with that of Herbert et al. (1996). The two models were based on predictions that were developed using different growth functions for height. While they predicted similar values until around age 40 years, the shapes of the models were different (Figure 15). From age 40-60, and then extrapolated to age 80, Herbert et al. (1996) projected volume increment in an almost linear form. The projections from age 50-60 were not supported by the current model, nor were the extrapolated values to age 80 years and older. In planted stands with either 
Table 4 Estimates of stand growth for planted kauri stands at given ages. Values to age 80 are modelled on actual performance

\begin{tabular}{|c|c|c|c|c|c|}
\hline Age & Height $(\mathrm{m})$ & Basal Area $\left(\mathrm{m}^{2} \mathrm{ha}^{-1}\right)$ & Volume $\left(\mathrm{m}^{3} \mathrm{ha}^{-1}\right)$ & Volume MAI $\left(\mathrm{m}^{3} \mathrm{ha}^{-1} \mathrm{yr}^{-1}\right)$ & Volume PAI $\left(\mathrm{m}^{3} \mathrm{ha}^{-1} \mathrm{yr}^{-1}\right)$ \\
\hline 10 & 2.8 & 0.6 & 1.1 & 0.1 & 0.1 \\
\hline 20 & 8.6 & 8.3 & 35.8 & 1.8 & 3.5 \\
\hline 40 & 17.1 & 47.1 & 343.2 & 8.6 & 15.4 \\
\hline 60 & 22.3 & 78.1 & 702.6 & 11.7 & 18.0 \\
\hline 80 & 25.7 & 92.6 & 936.8 & 11.7 & 11.7 \\
\hline
\end{tabular}

higher stand density or better performance there is an indication of an asymptote effect seen by age 40-50 at the oldest.

The models of height (Herbert et al.), basal area (Herbert et al., and Chikumbo and Steward), and volume (Herbert et al.) were the only models of growth and productivity available for New Zealand kauri in planted stands. Growth and productivity models have been developed for few other Agathis species. The exceptions are three species of kauri from Queensland, Australia and one grown in Indonesia. Volume regression equations and estimates have been developed for $A$. robusta (two provenances), and one mixed stand of $A$. atropurpurea (B.Hyland) and A. microstachya (J.F.Bailey \& C.T. White) that were established in South Africa (Bredenkamp 1981). Site index for A. loranthifolia (Salisb.) was modelled using site elevation as an environmental factor but no relationship was found (Parthama, and Habagung 1985). Modelling approaches have been inconsistent and are species, site and characteristic specific.

The relationship between mean stand diameter and stand density has not previously been investigated for kauri. The relationship was strong and indicated the point at which mean stand diameter and basal area increment slows, and where self-thinning would likely occur unless a silvicultural thinning was undertaken. Using a simple visual assessment resulted in little deviation of stands assumed to be at or near full site occupancy. Six of the current planted stands had reached or were approaching the self-thinning line and had a current annual diameter increment of $0.38 \mathrm{~cm} \mathrm{yr}^{-1}$ against a mean of $0.61 \mathrm{~cm} \mathrm{yr}^{-1}$ MAI for all stands. The two stands used by Herbert et al. to model productivity had quadratic diameters that were marginally in excess of

Table 5 The planted stand models for mean top height and basal area were validated using the one-at-a-time cross-validation method

\begin{tabular}{llllll}
\hline & MTH & & & \multicolumn{2}{l}{ Basal area } \\
\cline { 2 - 3 } \cline { 6 - 6 } & RMSE & Bias & & RMSE & Bias \\
\hline Model & 1.301 & 0.09 & & 7.58 & 0.44 \\
Validation & 1.555 & 0.37 & & 8.327 & 0.41 \\
\hline
\end{tabular}

the predicted diameter (Equation 5) from the relationship between diameter and stand density.

The models developed in this study have shown growth and productivity of kauri in planted stands to be higher than previous estimates, and substantially higher than historical observations suggested possible (Matthews 1905; Laing and Blackwell 1907). Kauri is slow to establish with little height growth and volume production in the first 5-15 years after planting. Once established and growing actively, kauri were shown to have volume current increments of 17-18 $\mathrm{m}^{3} \mathrm{ha}^{-1} \mathrm{yr}^{-1}$. The development and application of appropriate management regimes, and a programme to select and breed kauri for production should allow for substantial improvements in early growth and productivity. The lack of knowledge in site selection, after-planting maintenance and silviculture indicates that the productivity estimates obtained to date are likely to be conservative.

Kauri height growth expressed by site index was not influenced by the site parameters for each stand, although there was a negative relationship between site index and age with younger stands having a higher predicted site index than older stands. This was most apparent for stands less than 20 years old. Historically, kauri grew on a much wider range of sites than where it is currently found. The species was widespread in New Zealand until the

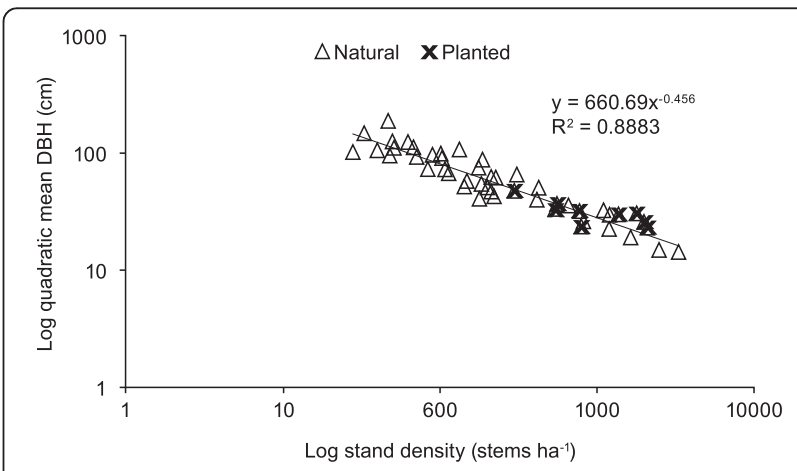

Figure 11 Relationship between quadratic mean diameter and stand density based on data from planted and natural stands where kauri was the dominant species and where full site occupancy was assumed. 


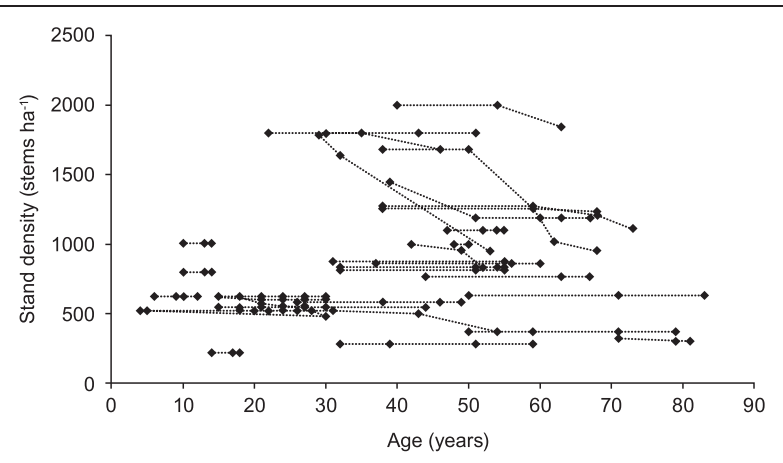

Figure 12 Changes in stand density, without thinning, for all planted kauri stands. Data points for individual stands are connected.

Pleistocene epoch $(400,000-14,000$ years BP), when glaciation caused retreat to the northern half of the North Island. Resin of kauri has been identified in fossilised material found in Tertiary lignite deposits in the Roxburgh and Mataura areas of the South Island (Evans, 1937). This suggests that locations where kauri have been planted outside what is considered its natural range are actually sites well within the species wider tolerances for soils and climate. What is considered the "natural range" of the species could therefore be reconsidered.

The models indicate a slow or extended establishment phase in kauri for young seedlings and saplings. This is most likely attributable to a number of factors. While the majority of the stands used in this study were established as woodlots, none of the expected management after planting was undertaken. The root development of kauri seedlings can be poor. Young kauri have a well-developed taproot, and it is possible that penetration and exploitation of free-draining soils is important for optimum growth (Morrison and Lloyd 1972). Therefore, slow development of roots after establishment may account for the slow establishment of planted seedlings (Bergin and Steward 2004). Nursery practice and the development of appropriate sized and aged seedlings are also likely to play a part in the early growth of kauri. It is common for kauri to be raised in PB3 planter bags (that contain the equivalent of 3 pints of potting mix) or similar containers, with seedlings up to one metre tall, or more. As the moisture and fertility requirements are supplied artificially to a seedling in a nursery situation it is easier to grow seedlings where a large top is out of proportion to the root system. Hence, seedlings may take some time after planting to re-establish an appropriate root structure able to support the top and initiate growth. A further important consideration was the lack of knowledge of the seed source for individual stands, the number of parent trees from which collections were made and the size of the parent stand. The productivity in some stands may therefore simply reflect poor seed collection techniques where only a narrow genetic base is represented. A 'juvenile' ontogenetic phase of slower growth may also be the cause. These explanations must be tested in order to achieve early site capture and improve site productivity if kauri is to be planted for production.

The growth and productivity of one stand (Stand 16) was considerably in excess of all other stands. Diameter MAI did not fall below $1.7 \mathrm{~cm} \mathrm{yr}^{-1}$ for the six years that it was assessed, and had been as high as $2.6 \mathrm{~cm} \mathrm{yr}^{-1}$ for periodic mean annual increment. Height MAI was not below $0.9 \mathrm{~m} \mathrm{yr}^{-1}$ during the measurement period. At age 14, the largest kauri had reached $30 \mathrm{~cm} \mathrm{DBH}$ $\left(2.14 \mathrm{~cm} \mathrm{yr}^{-1}\right)$. It is unknown whether this stand represents the absolute maximum growth for kauri, and whether the rate of growth in the stand will be maintained. Both these points will be the subject of further observation.

McConchie (1999) suggested that timber properties of native species would be largely age-dependent and would be compromised by pursuing (excessively) short rotations. A detailed study of wood quality was undertaken from material recovered from 68-year old planted kauri (Steward and McKinley 2005). The stems selected for the study were the largest diameter trees, therefore the fastest growing element of the stand. The wood properties

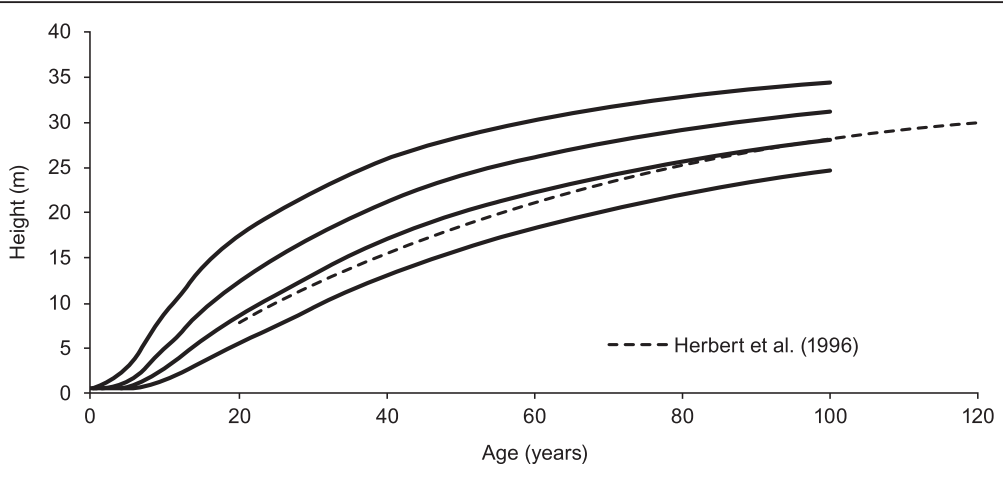

Figure 13 Comparison of height predictions between the current model ( 25 stands) shown in Figure 4 and that of Herbert et al. ( 2 stands). 


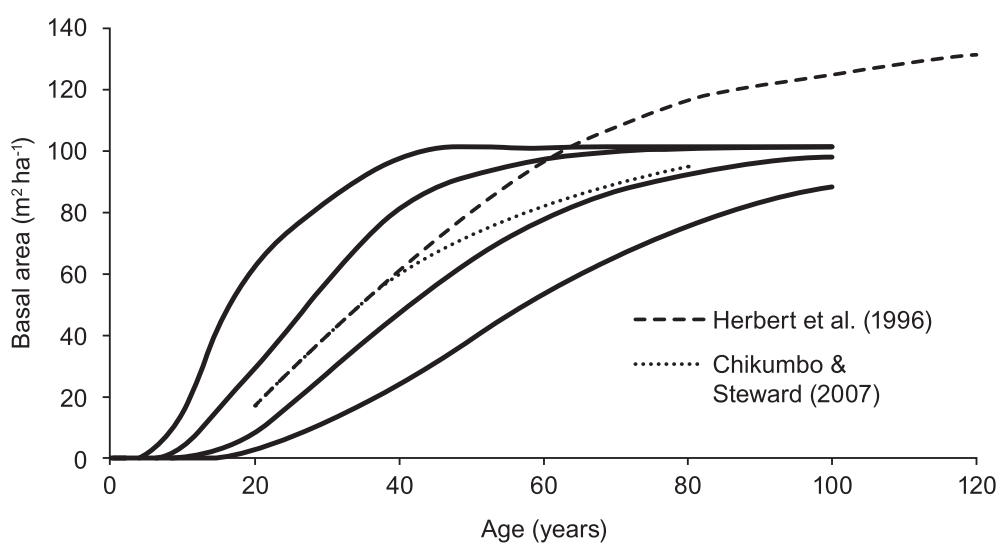

Figure 14 Comparison of basal area predictions between the current model ( 25 stands) shown in Figure 7 and those of Herbert et al. (2 stands) and Chikumbo and Steward (13 stands).

of logs largely comprised of sapwood were similar to those of old-growth heartwood and second-growth mixed sapwood/heartwood timber for stiffness and shrinkage, but slightly inferior for basic density, and were uniform across the width of the stem. A recent study of wood density of kauri in eleven planted stands that ranged in age from 14 to 69 years-old indicated an average density of $448 \mathrm{~kg} \mathrm{~m}^{3}$ for trees largely comprised of sapwood (G. Steward unpublished data). Wood density was not affected by age, diameter, growth rate, stand density, latitude, or any other site variable. Wood density in planted stands was also similar to that found in second-growth natural stands where individual kauri were up to 287 years old. This suggests that the observations of McConchie (1999) do not apply to kauri as the growth rates observed did not negatively influence wood quality.

The models used here indicate that kauri planted and grown on suitable sites can produce useful volumes in rotations as short as 60 years. The diameter data from the current study of growth and productivity indicates that quadratic DBH at age 60 years would be $37.4 \mathrm{~cm}$ and $45.7 \mathrm{~cm}$ for mean top DBH for all planted stands

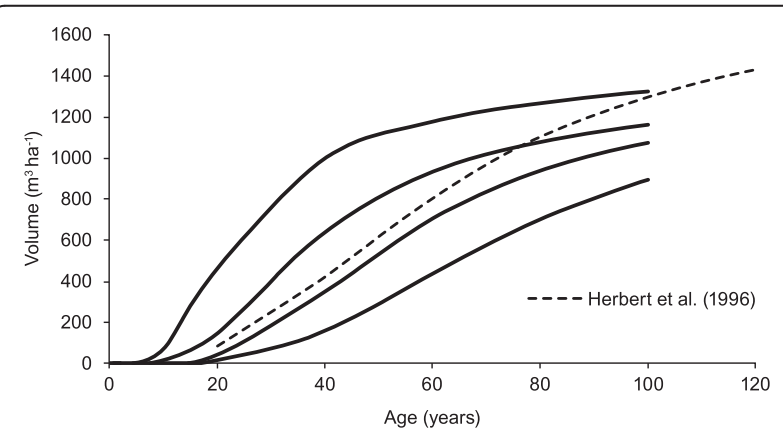

Figure 15 Comparison of volume predictions between the current model ( 25 stands) shown in Figure 10 and that of Herbert et al. (2 stands). combined. Best performing planted stands would have DBH ca. $55.0 \mathrm{~cm}$ at age 60 . A previous wood quality study of kauri in planted stands (Steward and McKinley 2005) examined the variables of wood density, shrinkage and stiffness of sapwood boards milled from 68-year old stems. For these variables, observed values were found to be similar to or better than old-growth heartwood, and were uniform pith to bark. If it is assumed that wood quality across all sites is the same or similar to that found in the study of Steward and McKinley (Steward and McKinley 2005) then harvesting for timber from kauri grown in planted stands could occur at age 60 , or earlier. A commercial harvest or thinning could occur as early as age 50, as mean top DBH was estimated to be $39.7 \mathrm{~cm}$ and quadratic mean DBH was estimated to be $31.7 \mathrm{~cm}$ at this age. These values are also well within the DBH range for logs tested from the two Taranaki studies of Herbert et al. These rotation lengths compare to 40-year rotations for Agathis dammara Warb. in Indonesia (Bruijnzeel et al. 1985), 35-40 years for Agathis sp. in South Africa (Bredenkamp 1981), 40-45 years for Araucaria cunninghamii Aiton ex D.Don in Queensland (Huth et al. 2009), 45-50 years (estimated) for Agathis macrophylla (Lindl.) Mast. in Vanuatu and Fiji (Keppel et al. 2009), and 40-45 years for A. lanceolata and A. moorei (Lindl.) Mast. in plantations in New Caledonia (Direction Du Développement Rural 2002).

The models developed here of height, basal area and volume are based on data for kauri in the monopodial form only. Diameter and height were found to be strongly correlated, with DBH being a good predictor of total tree height. Models of growth and productivity for kauri in stands where a mature form predominates (i.e. a large spreading crown) will need to be developed separately if kauri is grown over longer rotations to produce heartwood or to store carbon, and where diameters of $1.0 \mathrm{~m}$ or more might be required. 
The kauri dieback disease Phytophthora taxon Agathis (PTA) (Beever et al. 2007; Gadgil 1974) that is affecting kauri in the northern distribution of the species poses a risk not only to the survival of the species, but also its potential productivity. The current mature kauri population represents only an estimated $0.5 \%$ of the original forest that existed before Maori burning and European logging (Steward and Beveridge 2010). It is typified by numerous small, disjunct populations spread throughout its natural range. If the economic potential of kauri can be unlocked then growing kauri in plantations in-situ and ex-situ is a potential means by which both conservation and production outcomes might be achieved. Selection and breeding programmes for production will rely on some knowledge of the species genetic diversity that will be useful in determining the extent of natural genetic variation, which will facilitate any future breeding, conservation and genetic management of kauri. Combined with information on natural resistance within the kauri population, to PTA and other diseases, this information will help build an informed management strategy to ensure the long-term existence of this species in the landscape.

Numerous historical and contemporary references indicate that kauri has a potential role in the development of New Zealand's economic well-being (Hutchins 1919; Herbert et al. 1996; New Zealand Forest Research Institute 1997). Planting of kauri in New Zealand will continue, and the rate is likely to increase, both within and outside the current natural range of the species. Careful management is likely to allow the production of a very desirable timber over much shorter rotations than were previously thought to be possible. Those wishing to plant kauri for future timber production will require more information about best-practice regimes and potential yield. Continued development of techniques and growth models is likely to accelerate the expansion of a unique national resource.

\section{Endnote}

${ }^{\text {a }}$ Site index refers to the timber potential for a site for a particular species, usually at a fixed age somewhere near the expected rotation length for the species. In forestry, the usual method to develop site index is from stand height records, as good site quality is also often reflected in good height growth (Clutter et al. 1983).

\section{Additional files}

Additional file 1: Stand and site variables for all planted kauri. Sites are ranked by latitude (north to south).

Additional file 2: Root Mean Square Error (RMSE) and bias for models tested for predominant mean height and basal area (preferred models bolded).
Additional file 3: Age, size, performance and productivity of all planted kauri stands. (Values are at the last assessment. Sites are arranged youngest to oldest)

\section{Competing interests}

The authors declare that they have no competing interests.

\section{Authors' contributions}

GAS undertook the latest measurements of the kauri stands, compiled the databases, initial analysis of the data and drafted the manuscript. MOK assisted with analysis and development of the models, EGM assisted with the design of the study and development of the models. HSD assisted with the manuscript. All authors read and approved the manuscript.

\section{Acknowledgements}

We are indebted to those people and organisations that made their developing stands available for measurement and inclusion in this study. We would also like to acknowledge those individuals who made the early observations of individual stands. The authors thank the reviewers of this paper for their comments. This study was made possible through the support of the Future Forest Research Diverse Species Theme with funding from the Ministry of Science and Innovation Contract No C04X0805.

\section{Author details}

${ }^{1}$ New Zealand Forest Research Institute Ltd. (Scion), Private Bag 3020, Rotorua, New Zealand. 'University of Canterbury, Private Bag 4800, Christchurch 8140, New Zealand.

Received: 27 November 2013 Accepted: 30 October 2014

Published online: 18 November 2014

\section{References}

Ahmed, M, \& Ogden, J. (1987). Population dynamics of the emergent conifer Agathis australis (D. Don) Lindl. (kauri) in New Zealand. I. Population structures and tree growth rates in mature stands. New Zealand Journal of Botany, 25(2), 217-229.

Beekhuis, J. (1966). Prediction of Yield and Increment in Pinus Radiata Stands in New Zealand (Vol. Technical Paper No. 49). Wellington: NZ Forest Service, Forest Research Institute, Technical Paper No. 49.

Beever, RE, Waipara, NW, Ramsfield, TD, Dick, MA, \& Horner, IJ. (2007). Kauri (Agathis australis) Under Threat from Phytophthora? In Proceedings of 4th IUFRO Phytophthoras in Forests and Natural Ecosystems, Monterey, August, 2007

Bergin, DO, \& Gea, L. (2007). Native Trees - Planting and Early Management for Wood Production (Revised ed.). New Zealand Indigenous Tree Bulletin No. 3. Rotorua: New Zealand Forest Research Institute.

Bergin, DO, \& Steward, GA. (2004). Kauri: Ecology, Establishment, Growth, and Management. New Zealand Tree Bulletin No. 2. Rotorua: New Zealand Forest Research Institute.

Bredenkamp, BV. (1981). Kauri pine - a place in South African forestry? South African Forestry Journal, 116(March), 17-22.

Bruijnzeel, LA, Sampurno, SP, \& Wiersum, KF. (1985). A nutrient balance sheet for Agathis dammara Warb. plantation forest under various management conditions in Central Java, Indonesia. Forest Ecology and Management, 10(3), 195-208

Cancino, J. (2005). Modelling the edge effect in even-aged Monterey pine (Pinus radiata D. Don) stands. Forest Ecology and Management, 210(1-3), 159-172.

Chapman, DG. (1961). Statistical Problems in Dynamics of Exploited Fisheries Populations. In J Neyman (Ed.), Proceedings of the 4th Berkeley Symposium on Mathematics, Statistics and Probability (Vol. IV, pp. 153-168). Berkeley: University of California Press.

Cheeseman, TF. (1914). Illustrations of the New Zealand Flora (Vol. II). Wellington: Government Printer.

Chikumbo, O, \& Steward, GA. (2007). A stand basal area model for plantation grown New Zealand kauri. Ecological Modelling, 209(2-4), 367-376.

Clifton, NC. (1990). New Zealand Timbers. The Complete Guide to Exotic and Indigenous Woods. Wellingon: GP Publications Ltd.

Clutter, JL, Forston, JC, Pieenar, LV, Brister, GH, \& Bailey, RL. (1983). Timber Management: A Quantitative Approach (Reprintth ed.). Malabar, Florida: Krieger Publishing. 
Cockayne, L. (1928). The Vegetation of New Zealand (2nd ed.). Leipzig: Englemann. Colenso, W. (1868). Essay on the botany, geographic and economic, of the North Island of the New Zealand Group. Transactions and Proceedings of the Royal Society of New Zealand, 1868-1961(1), 1-54.

Cranwell, LM, \& Moore, LB. (1936). The occurrence of kauri in montane forest on Te Moehau. New Zealand Journal of Science and Technology, 18, 531-543.

Department of Survey and Land Information. (1989). NZMS 260 Series Edition 1 1:50,000 scale, Wellington, New Zealand (1st ed.). Wellington, New Zealand: Government Printer.

Direction Du Développement Rural. (2002). Visites de plantations forestières kaoris et Araucarias et de la Pépinière de la Province. Symposium field tour (March 2002). Paper presented at the Araucariaceae: Proceedings of the 2002 Araucariaceae Symposium, Araucaria-Agathis-Wollemia. Noumea: Service des productions végétales et des forêts.

Ecroyd, CE. (1982). Biological flora of New Zealand. 8. Agathis australis (D. Don) Lindl. (Araucariaceae) kauri. New Zealand Journal of Botany, 20(1), 17-36.

Ecroyd, CE, Herbert, JW, Miller, JT, \& Horgan, GP. (1993). Kauri... potential fo plantation forestry. Growing Today, 20-23.

Efron, B, \& Tibshirani, RJ. (1993). An Introduction to the Bootstrap. New York: Chapman and Hall, International Publishing.

Ellis, JC. (1979). Tree Volume Equations for the Major Indigenous Species in New Zealand (p. 64). Wellington, New Zealand: New Zealand Forest Service Technical paper No. 67.

Ellis, JC, \& Hayes, JD. (1991). Minimum Standards for Collection of Growth Data from Permanent Sample Plots. Rotorua, New Zealand: Report No. 4 of Stand Growth Modelling Cooperative. 1991 revision.

Evans, WP. (1937). Note on the flora which yielded the tertiary lignites of Canterbury, Otago and Southland. New Zealand Journal of Science and Technology, 19(3), 188-193.

Gadgil, PD. (1974). Phytophthora heveae, a pathogen of kauri. New Zealand Journal of Forestry Science, 4(1), 59-63.

Halkett, JC. (1983). Kauri Forest Management Review. Kauri Management Unit, Auckland Conservancy: New Zealand Forest Service.

Herbert, JW, Glass, B, \& Kimberley, MO. (1996). A Preliminary Stand Productivity and Economic Case Study of Plantation Growth Kauri. In An Alternative Approach to Forestry - Time to Review. Proceedings of the New Zealand Institute of Forestry Conference (pp. 83-91). Invercargill: New Zealand Institute of Forestry.

Hutchins, DE. (1919). New Zealand Forestry Part 1. Kauri Forests and Forests of the North and Forest Management. Government Printer: Wellington.

Huth, J, Last, I, \& Lewty, M. (2009). The Hoop Pine Story - from Rainforest Emergent to Native Plantations. In RL Bieleski \& MD Wilcox (Eds.), Araucariceae: Proceedings of the 2002 Araucariaceae Symposium, Araucaria-Agathis-Wollemia (pp. 297-306). Dunedin: The International Dendrology Society.

Keppel, G, Thompson, L, \& Senivasa, E. (2009). Agathis macrophylla - a review of Melanesia's big tree. In RL Bieleski \& MD Wilcox (Eds.), Araucariaceae: Proceedings of the 2002 Araucariaceae Symposium, Araucaria-Agathis-Wollemia (pp. 375-382). Dunedin: International Dendrology Society.

Laing, RM, \& Blackwell, EW. (1907). Plants of New Zealand. Christchurch, N.Z: Whitcombe and Tombs Limited.

Littell, RC, Milliken, GA, Stroup, WW, \& Wolfinger, RD. (1996). "SAS System for Mixed Models", Chapter 12. Cary, NC: SAS Institute Inc.

Lloyd, RC. (1978). Kauri Volumes. Kauri Management Unit, Auckland Conservancy: New Zealand Forest Service.

Matthews, HJ. (1905). Tree-culture in New Zealand. Wellington: Governent Printer.

McConchie, DL. (1999). Quality Native Timber from Future Managed Stands. In W Silvester \& R McGowan (Eds.), Native Trees for the Future (pp. 15-19). Hamilton: University of Waikato.

Morrison, FT, \& Lloyd, RC. (1972). Artificial establishment of New Zealand kauri at Waipoua. New Zealand Journal of Forestry, 17(2), 264-273.

New Zealand Forest Research Institute. (1997). Native Trees for Production Forestry. In What's New in Forest Research (Vol. 243). Rotorua: Rotorua Printers.

New Zealand Meteorological Service (1983). Summaries of climatological observations to. (1980). New Zealand Meteorological Services Miscellaneous Publication 177. Wellington: Ministry of Transport.

Pardy, GF, Bergin, DO, \& Kimberley, MO. (1992). Survey of Native Tree Plantations. FRI Bulletin - New Zealand Ministry of Forestry. 175. Rotorua: Forest Research Institute.

Parthama, IBP, \& Habagung. (1985). Site-index model of Agathis loranthifolia. Buletin Penelitian Hutan, Pusat Penelitian dan Pengembangan Hutan, 463, 44-62.
Pienaar, LV, \& Turnbull, KJ. (1973). The Chapmans-Richards generalization of Von Bertalanffy's growth model for basal area growth and yield in even-aged stands. Forest Science, 19(1), 2-22.

Reineke, LH. (1933). Perfecting a stand-density index for even-aged forests. Journal of Agricultural Research, 46, 627-638.

Richards, FJ. (1959). A flexible growth function for empirical use. Journal of Experimental Botany, 10(29), 290-300.

Roche, MM. (1990). History of New Zealand Forestry. Wellington, New Zealand: New Zealand Forestry Corporation with G.P. Books.

Sando, CT. (1936). Notes on Agathis australis. New Zealand Journal of Forestry, $4(1), 16-21$

Schumacher, FX. (1939). A new growth curve and its application to timber yield studies. Journal of Forestry, 37, 819-820.

Steward, GA. (2011). Growth and yield of New Zealand kauri (Agathis australis (D Don Lindl.)). Msc. Thesis Christchurch: University of Canterbury.

Steward, GA, \& Beveridge, AE. (2010). A review of New Zealand kauri (Agathis australis (D.Don) Lindl.): its ecology, history, growth and potential for management for timber. New Zealand Journal of Forestry Science, 40(2010), 33-59.

Steward, GA, \& McKinley, RB. (2005). Plantation-grown New Zealand kauri: a preliminary study of wood properties. New Zealand Journal of Forestry Science, 35(1), 35-49.

von Bertalanffy, L. (1949). Problems of organic growth. Nature, 163(4135), 156-159.

Von Hochstetter, F. (1867). New Zealand, its Physical Geography, Geology, and Natural History. Stuttgart: J.G. Cotta.

Weibull, W. (1939). A statistical theory of the strength of materials. Royal Swedish Institute for Engineering Research, Stockholm, Ingeniors Vetenskaps Akademiens Handlingar, 151, 45.

Yang, RL, Kosak, A, \& Smith, HJG. (1978). The potential of Weibull-type functions as flexible growth functions. Canadian Journal of Forest Research, 8, 424-431.

Yoda, K, Kira, T, Ogawa, H, \& Hozumi, K. (1963). Self-thinning in over-crowded pure stands under cultivated and natural conditions (Intraspecific competition among higher plants XI). Journal of the Institute of Polytechnics, Osaka City University, Series, D14, 107-129.

\section{doi:10.1186/s40490-014-0027-2}

Cite this article as: Steward et al.: Growth and productivity of New Zealand kauri (Agathis australis (D.Don) Lindl.) in planted forests. New Zealand Journal of Forestry Science 2014 44:27.

\section{Submit your manuscript to a SpringerOpen ${ }^{\odot}$ journal and benefit from:}

- Convenient online submission

- Rigorous peer review

- Immediate publication on acceptance

- Open access: articles freely available online

- High visibility within the field

- Retaining the copyright to your article

Submit your next manuscript at springeropen.com 